\title{
Open Educational Resources and University Social Responsibility Practices among Thailand's Higher Education Institutional Management
}

\author{
Shu-Hsiang Chen, Jaitip Nasongkhla, and J. Ana Donaldson
}

\begin{abstract}
Unequal access to higher education institutions (HEIs) on the basis of gender, economic and social status, location of residence, and inadequate prior schooling are all continuing to challenge many Asian nations. Open educational resources (OER) are one example of an innovative approach to educational technology which opens up opportunities to create, share, and facilitate teaching and learning. Embedding OER within University Social Responsibility (USR) is a key element for fostering transparency in educational learning processes, fulfilling higher education institutions (HEIs) social responsibility mission, and helping the establishment of a new sustainable development model for education. This study examined university managers' opinions and attitudes toward current OER and USR practice, particularly focused on Thai HEIs systems. A paper-based survey was deployed to three Thai HEIs systems including: (1) the Universities System (US), (2) the Rajabhat Universities System (RUS), and (3) the Rajamangala Universities of Technology System (RUTS). Forty-four university managers participated in this study. The findings of this study provide benefits to scholars in the field of educational technology and university policy and administration, with regard to supporting existing educational strategy planning and perhaps moving educational policy development further along. Future research can be looked at from the differing angles of the growing OER and USR movements allowing for individual, institutional, and country-level contributions..
\end{abstract}

Index Terms - Open educational resources, university social responsibility, OERs, USR, policy and strategic planning.

\section{INTRODUCTION}

Unequal access to higher education institutions (HEIs) on the basis of gender, socioeconomic status, geographic location and prior schooling all continue to challenge many Asian nations and present obstacles to the larger goals of sustainable development. The Internet revolution has allowed for some of these inequities to be offset through the evolution of an 'openness' movement, a potentially transformative approach to education that fosters the free flow of information and educational resources and can shift the traditional paradigm of higher education. Open educational resources (OERs) are a recent and innovative form of educational technology, which open up opportunities

Manuscript received March 22, 2017; accepted December 15, 2017.

Shu-Hsiang Chen and Jaitip Nasongkhla are with Chulalongkorn University, Department of Educational Technology and Communications, Faculty of Education, Bangkok, Thailand (e-mail: ava1019@gmail.com, jaitip.n@chula.ac.th).

J. Ana Donaldson is with University of Northern Iowa, USA (e-mail: ana.donaldson@cfu.net). for increased creation, communication, collaboration and connection among learners around the world. The trends and movement associated with OERs have become more prominent over time, not as a passing phenomenon, but as a way of improving the overall quality of education itself. OERs can be a powerful driver of innovation in education because they provide a strategic opportunity for HEIs to improve the quality of education and to connect knowledge sharing and capability building in terms of both human capital and social capital for the global citizen [1]-[4], while also serving to "leverage education and lifelong learning for the knowledge economy and society" [5].

When considering OERs as part of the larger landscape of HEIs, OERs have the potential to be a powerful driver of change if they are embedded into a university's guiding vision. OERs can create a space where the university and its stakeholders (students, faculty members, administrators, staff or outside experts) can come together within the openness movement and common learning space to share and disseminate the ideas, knowledge, or materials that they have produced, with the ultimate aim of ensuring all the materials are available to other people and without cost [6]. Although OERs have been developed through various initiatives and projects over the last decade, the view of OERs as mere resource repositories can and should be expanded to incorporate the deeper significance they hold in terms of learning and teaching pedagogy. As powerful and transformative as OERs can be, they are not sustainable in a vacuum. To thrive, they need the support and input from diverse aspects of university administration such as university social responsibility, policies and strategic development.

\section{LITERATURE REVIEW}

\section{A. Open Educational Resources}

OECD [3] defines OER as "OER is digitized materials offered freely and openly for educators, students, and self-learning to use and reuse for teaching, learning and research ... including learning content, software tools to develop, use and distribute content, and implementation resources such as open licenses" (p. 10). Butcher [6] states that OERs are "any educational resources (including curriculum maps, course materials, textbooks, streaming videos, multimedia applications, podcasts, and any other materials that have been designed for use in teaching \& learning" (p.5). Additionally, Arnold [1] refers to OERs as "all educational materials, like learning resources, 
technologies and structures that are easily accessible, with low or no barriers in terms of costs, technology or license fees and royalties" (p. 2). Based on the above definitions, this study defines OERs as any type of educational resources, either print or digital format (including course materials and websites, textbooks, audio materials, podcast, video, multimedia applications, images or visual materials, archived discussions, simulations or animations, maps, ancient or historical manuscripts, software, and any other tools or technical used to support access knowledge) that reside in the public domain and have been released under an intellectual property license or open license such as Creative Commons that permits users, according to the 5Rs Openness framework to: retain, reuse, revise, remix, and/or redistribute [7]-[9] to support knowledge building, sharing and learning to the worldwide community.

\section{B. University Social Responsibility}

The term, "university social responsibility" (USR) may be defined as: "a policy of ethical quality in the activities of the university community (students, lectures, administrative staff), through the responsible management of the educational, cognitive, labor and environmental impacts of the university, in a participative dialogue with society to promote sustainable human development in four steps: 1) commitment; 2) self-diagnosis; 3) compliance; and 4) accountability" [9]. Alternatively, it may be described as "a university's engagement and that university's partnership with its communities, as achieved through education (transferring knowledge), provision of services, research, teaching and scholarship" [10]. USR can therefore be perceived as the philosophy of a university which takes an ethical approach to the development and engagement with the local and global community in order to sustain social, ecological, environmental, technical, and economic development. USR depicts an ethical collaboration not only with the university community, but also within the larger ecology as a significant of stakeholder [11]-[13].

Globally, universities can benefit from adopting a social responsibility strategy, much like other businesses organizations do (often referred to as 'corporate social responsibility' (CSR)), in order to meet the expectations of their external stakeholders (students, employers of graduates, funding agencies and society as a whole) as well as internal stakeholders within universities administrators, faculty and staff. USR is an important aspect of how universities interact with their internal and external stakeholders and society. Building upon a review of the existing literature concerning university social responsibility, a USR framework has been developed. This framework, termed SCOPE (social, sub-social, cognitive, organizational, philanthropic, economic, ethic, environmental, and educational) was developed [14], [15] that serves to examine and assess university administrators' opinions toward to their current USR practices.

Currently, many existing OER initiatives are making efforts to push for adoption as a next step. The case for promoting and sustaining OER within university policy and strategy has already been discussed before. For example, UNESCO [16] in the Paris OER Declaration expressed desire to move OER development onto a global scale. However, the support from global institutions regarding OER policy and strategic development is still limited [3]. Based on this research, the case can be made that linking the ideals of open educational resources to university social responsibility can foster more transparency within higher education and contribute to the larger goal of a sustainable model of education that serves the interests of society as a whole.

To date, very little research has been conducted on the policy development and strategic planning needed support and foster OER development within policy and strategy. As such, a good starting point for HEIs is to consider the development of a clear policy and strategic plan that is more aligned with their current university practices, in addition to creating services that can truly extend the use and development of OERs in HEIs. As a result of this research, and the questions raised by it, this study aimed to examine university managers' opinions and attitudes toward current OER and USR practices, focusing in particular on HEIs in Thailand. The research objective of this study was to gather Thai university managers' attitudes, opinions, and perceptions toward open educational resources and university social responsibility and to explore how these two concepts may potentially reinforce each other if embraced on the level of university policy and strategic planning.

\section{RESEARCH METHODOLOGY}

A survey approach was chosen to examine Thai university managers' attitudes and opinions regarding current open educational resources and university social responsibility practices. A paper-based survey was deployed and sent to three different types of Thai HEIs systems: 1) the Universities System (US);2) the Rajabhat Universities System (RUS); and 3) the Rajamangala Universities of Technology System (RUTS). A purposive sampling method was employed based on their curriculum, a curriculum which offers degrees in educational technology and er information technology. The participants of this study included university presidents, vice presidents, deans of faculty, deputy deans, associate deans, assistants to the deans, heads of departments, heads of divisions, and other representatives who have all been involved in university strategic planning. The structure of the survey questions were based on the previous literature [7]-[13], [17]-[28] and the questions were modified based on the needs of this study. The content validity of the survey was by a number of experts to verify the wording of the survey questions according to the Index of the Item-Objective Congruence (IOC) [29] approach. These experts were asked to provide comments and evaluate each item in order to enhance the clarity, readability, and relevance of the questions.

\section{A. Participants}

The Thai Office of Higher Education Commission (OHEC) has identified 171 Thai Higher Education Institutions (HEIs). In order to fulfill the diverse needs, focus and levels of academic development of different target groups, the OHEC has classified the Thai HEI system into four groups:

1) The Universities System (US), includes both public and 
private institutions with a concentration on postgraduate research in order to enhance the nation's competitiveness;

2) The Rajabhat Universities System (RUS), originally the teachers' college system includes four-year teaching universities with a focus on liberal arts at the undergraduate level - a well-known hub of local knowledge, wisdom, and experience;

3) The Rajamangala Universities of Technology System (RUTS), specialize in producing skilled graduates for the manufacturing and real sectors;

4) Community Colleges (CC) flexible study programs at lower than degree level that focus on rural and community development.

The survey was distributed to the above three types of Thai HEI systems (US, RUS, and RUTS). A total of 44 out of the 60 HEIs we administered the survey to $(73.33 \%)$ answered the survey (Table I). The respondents were organized according to their position: (1) Others (Professors, Associate Professors, Assistant Professors) (20.45\%); Associate Deans (15.91\%); Assistants to the President (11.36\%); Vice Presidents (11.36\%); Acting Presidents (9.09); Center Directors (9.09\%); Presidents (6.82\%); Deputy Deans (6.82\%); Heads of Department (4.55\%); and Deans (2.27\%).

TABLE I: SURVEY RESPONDENTS

\begin{tabular}{|c|c|c|c|}
\hline $\begin{array}{l}\text { University } \\
\text { type }\end{array}$ & $\begin{array}{l}\text { Universities } \\
\text { System (US) }\end{array}$ & $\begin{array}{l}\text { Rajabhat } \\
\text { Universities } \\
\text { System (RUS) }\end{array}$ & $\begin{array}{l}\text { Rajamangala } \\
\text { Universities of } \\
\text { Technology System } \\
\text { (RUTS) }\end{array}$ \\
\hline Sample & 30 & 21 & 9 \\
\hline Response & 22 & 15 & 7 \\
\hline $\begin{array}{l}\text { Respondent } \\
\text { Rate }\end{array}$ & $73.33 \%$ & $71.43 \%$ & $77.78 \%$ \\
\hline
\end{tabular}

\section{RESUlTS AND DisCUSSION}

The results of the survey were categorized under three headings: 1) an overview of the current status and practice of open educational resources; 2) an overview of current status and practice of university social responsibility; and 3) opinions toward OERs \& USR.

\section{A. Overview of Current Status and Practices of OERS}

This section covers the results of: 1) OER strategy and policy; 2) OER movement; 3) OER staff and faculty training development; and 4) OER infrastructure, support and incentives.

\section{B. OER Strategy and Policy}

The survey first examined the current status and practice of OERs strategy and policy (Table II) within their respective universities. Participants included $68.18 \%$ of the Universities System, 53.33\% of the Rajabhat Universities System, and $28.57 \%$ of the Rajamangala Universities Technology System. The results indicate that these institutions do currently have a strategy or policy on OERs. When examining each type of institution according to their current OER policy and strategic practice, each type of institution responded differently. As part of their knowledge management strategy the respondents from the Universities System identified providing eLearning and online courses, sharing open content among faculty members, and using open content or resources from an OER site, or using MOOCs, as part of the knowledge management strategy. In addition, the respondents from the Rajabhat Universities System described existing strategies in regards to 1) educational quality development and 2) developing people at every age in support of lifelong learning. In support of these efforts the university employs methods such as: creating e-learning materials (multimedia projects and video clips for each subject), using a learning management system, developing a database of IT networks and providing eLearning through distance learning TV (eDLTV) projects. In addition, the respondents from the Rajamangala Universities Technology System described the use of pictures, multimedia, video, or databases, and that they have a central website for lecturers to share materials- These examples may be considered as approaches to an OER strategy.

TABE II: OER STRATEGY OR POLICY STATUS

\begin{tabular}{|c|c|c|c|c|c|c|}
\hline $\begin{array}{l}\text { Does your } \\
\text { institution } \\
\text { currently have a } \\
\text { strategy or policy } \\
\text { for Open } \\
\text { Educational } \\
\text { Resources? } \\
\end{array}$ & \multicolumn{2}{|c|}{$\begin{array}{l}\text { Universities } \\
\text { System (US) }\end{array}$} & \multicolumn{2}{|c|}{$\begin{array}{l}\text { Rajabhat } \\
\text { Universities } \\
\text { System (RUS) }\end{array}$} & \multicolumn{2}{|c|}{$\begin{array}{l}\text { Rajamangala } \\
\text { Universities of } \\
\text { Technology } \\
\text { System (RUTS) }\end{array}$} \\
\hline & $\mathrm{F}$ & $\%$ & $\mathrm{~F}$ & $\%$ & $\mathrm{~F}$ & $\%$ \\
\hline Yes & 15 & 68.18 & 8 & 53.33 & 2 & 28.57 \\
\hline No & 7 & 31.82 & 7 & 46.67 & 5 & 71.43 \\
\hline
\end{tabular}

\section{1) OER movement}

The survey further inquired about participants' opinions regarding the status of currently active in the OER movement within their institutions (Table III). Respondents from the Universities System indicated increased efficiency and quality of learning resources $(86.36 \%$ ) as being the highest perceived benefit of OER, followed by open and flexible learning opportunities (59.09\%), cost-efficiency of OERs $(50 \%)$, the innovative potential of OERs $(45.45 \%)$, and other $(4.55 \%)$. These are the areas currently active in their OER movement. By contrast, the respondents from the Rajabhat Universities System revealed increased efficiency and quality of leaning resources $(73.33 \%)$ followed by the cost-efficiency of OERs (60\%), open and flexible learning opportunities (46.67\%), and the innovative potential of OERs $(33.33 \%)$, as being the areas currently activity in their OER movement. Finally, the respondents from the Rajamangala Universities Technology System noted open and flexible learning opportunities $(85.71 \%$ ) as being their first focus areas for an OER movement. For the rest of the focus areas, such as increased efficiency and quality of learning resources, the cost-efficiency of OERs, and the innovative potential of OERs, there existed a fairly equally distributed proportion $(42.86 \%)$ from respondents.

TABLE III: STATUS OF CURRENTLY ACTIVE IN THE OER MOVEMENT

\begin{tabular}{|c|c|c|c|c|c|c|}
\hline \multirow[t]{2}{*}{$\begin{array}{l}\text { Which of these areas } \\
\text { are currently active in } \\
\text { your institution } \\
\text { regarding the OER } \\
\text { movement? }\end{array}$} & \multicolumn{2}{|c|}{$\begin{array}{l}\text { Universities } \\
\text { System (US) }\end{array}$} & \multicolumn{2}{|c|}{$\begin{array}{l}\text { Rajabhat } \\
\text { Universities } \\
\text { System } \\
\text { (RUS) }\end{array}$} & \multicolumn{2}{|c|}{$\begin{array}{l}\text { Rajamangala } \\
\text { Universities of } \\
\text { Technology } \\
\text { System (RUTS) }\end{array}$} \\
\hline & $\mathrm{F}$ & $\%$ & $\mathrm{~F}$ & $\%$ & F & $\%$ \\
\hline $\begin{array}{l}\text { Open and flexible } \\
\text { learning } \\
\text { opportunities }\end{array}$ & 13 & 59.09 & 7 & 46.67 & 6 & 85.71 \\
\hline
\end{tabular}




\begin{tabular}{lcccccc}
\hline \hline $\begin{array}{l}\text { Increased efficiency } \\
\text { and quality of } \\
\text { learning resources }\end{array}$ & 19 & 86.36 & 11 & 73.33 & 3 & 42.86 \\
$\begin{array}{l}\text { Cost-efficiency of } \\
\text { OERs }\end{array}$ & 11 & 50.00 & 9 & 60.00 & 3 & 42.86 \\
$\begin{array}{l}\text { The innovative } \\
\text { potential of OERs }\end{array}$ & 10 & 45.45 & 5 & 33.33 & 3 & 42.86 \\
Other & 1 & 4.55 & 0 & 0.00 & 3 & 42.86 \\
\hline \hline
\end{tabular}

When further examining the main reasons that participants' institutions are active in the OER movement (Table IV), quality was indicated in both the Universities System $(72.73 \%)$ and the Rajabhat Universities System $(66.67 \%)$, whereas language and cultural diversity were indicated in the Rajamangala Universities of Technology System $(71.43 \%)$.

TABLE IV: RATIONALE FOR BEING ACTIVE IN THE OER MOVEMENT

\begin{tabular}{|c|c|c|c|c|c|c|}
\hline \multirow[t]{2}{*}{$\begin{array}{l}\text { Please provide the } \\
\text { main reason that } \\
\text { your institution is } \\
\text { active in the OER } \\
\text { Movement? }\end{array}$} & \multicolumn{2}{|c|}{$\begin{array}{l}\text { Universities } \\
\text { System (US) }\end{array}$} & \multicolumn{2}{|c|}{$\begin{array}{l}\text { Rajabhat } \\
\text { Universities } \\
\text { System (RUS) }\end{array}$} & \multicolumn{2}{|c|}{$\begin{array}{l}\text { Rajamangala } \\
\text { Universities of } \\
\text { Technology } \\
\text { System (RUTS) }\end{array}$} \\
\hline & $\mathrm{F}$ & $\%$ & $\mathrm{~F}$ & $\%$ & $\mathrm{~F}$ & $\%$ \\
\hline $\begin{array}{l}\text { Language and } \\
\text { cultural diversity }\end{array}$ & 7 & 31.82 & 3 & 20.00 & 5 & 71.43 \\
\hline Connectivity & 14 & 63.64 & 6 & 40.00 & 0 & 0.00 \\
\hline Quality & 16 & 72.73 & 10 & 66.67 & 4 & 57.14 \\
\hline $\begin{array}{l}\text { Copyright \& } \\
\text { publishers }\end{array}$ & 9 & 40.91 & 6 & 40.00 & 3 & 42.86 \\
\hline Sustainability & 8 & 36.36 & 6 & 40.00 & 3 & 42.86 \\
\hline Other reasons & 1 & 4.55 & 2 & 13.33 & 1 & 14.29 \\
\hline
\end{tabular}

The survey further examined the further status of OER movement from respondents as to whether or not their institution will become active in developing and/or using OERs in the near future (Table V). Both Universities System $(90.91 \%)$ and Rajabhat Universities System (100\%) have indicated continued future OER involvement.

TABLE V: FUTURE STATUS OF OER MOVEMENT

\begin{tabular}{|c|c|c|c|c|c|c|}
\hline \multirow[t]{2}{*}{$\begin{array}{l}\text { Will your } \\
\text { institution become } \\
\text { active in } \\
\text { developing and/or } \\
\text { using OER in the } \\
\text { near future? }\end{array}$} & \multicolumn{2}{|c|}{$\begin{array}{l}\text { Universities } \\
\text { System (US) }\end{array}$} & \multicolumn{2}{|c|}{$\begin{array}{l}\text { Rajabhat } \\
\text { Universities } \\
\text { System (RUS) }\end{array}$} & \multicolumn{2}{|c|}{$\begin{array}{l}\text { Rajamangala } \\
\text { Universities of } \\
\text { Technology } \\
\text { System (RUTS) }\end{array}$} \\
\hline & $\mathrm{F}$ & $\%$ & $\mathrm{~F}$ & $\%$ & $\mathrm{~F}$ & $\%$ \\
\hline Yes & 20 & 90.91 & 15 & 100.00 & 3 & 42.86 \\
\hline No & 2 & 9.09 & 0 & 0.00 & 4 & 57.14 \\
\hline
\end{tabular}

\section{2) OER staff and faculty training development}

The survey also asked participants to indicate whether or not their institution provides guidelines for creating, sharing, collaborating, and using OERs for staff and faculty training for OER development and adoption (Table VI). The 50\% of respondents from the Universities System indicated that their institution provides guidelines for creating, sharing, collaborating, and using OERs, and $90.91 \%$ that their institutions provides staff and faculty training for OER development and adoption. The respondents further specified the guidelines included the utilization of a learning management system, YouTube, a library, e-books, and information broadcasts as part of e-learning's open approach and open class within the school for creating, sharing, collaborating, and using OERs. In addition, the staff and faculty training session is usually provided by a specialized help desk, trainer, or librarian or invited subject matter expert speakers as part of a training workshop.

For the Rajabhat Universities System, 53.33\% indicated that there are guidelines provided by the university for creating, sharing, collaborating, and using OERs and 100\% of them indicated that their institutions do provide staff and faculty training for OER development and adoption, mostly by supporting attendance at seminars or conferences. One of the respondents from the Rajabhat Universities System described how, "the university has a policy to support and provide knowledge training for professors to develop educational learning resources."

For the Rajamangala Universities System, $85.71 \%$ of respondents indicated that the university does not provide guidelines for creating, sharing, collaborating, and using OERs, and indicated there only $42.86 \%$ of respondents' universities provided staff and faculty training for OER development and adoption. The respondents from the Rajamangala Universities Technology System suggested that there, "should be a pioneer group to provide and coordinate networking among universities involved in OER development", and suggested corresponding to "arrange a staff and faculty training session with an invitation letter". This may indeed foster OER development and adoption within the Rajamangala Universities Technology System.

TABLE VI: STAFF \& FACULTY TRAINING DEVELOPMENT FOR OER STATUS

\begin{tabular}{|c|c|c|c|c|c|c|}
\hline $\begin{array}{l}\text { Does your university } \\
\text { provide guidelines } \\
\text { for creating, sharing, } \\
\text { collaborating, and }\end{array}$ & & $\begin{array}{l}\text { rsities } \\
\text { m (US) }\end{array}$ & & $\begin{array}{l}\text { hat } \\
\text { rsities } \\
\text { n (RUS) }\end{array}$ & & $\begin{array}{l}\text { angala } \\
\text { rsities of } \\
\text { ology } \\
n \text { (RUTS) }\end{array}$ \\
\hline & $\mathrm{F}$ & $\%$ & F & $\%$ & $\mathrm{~F}$ & $\%$ \\
\hline Yes & 11 & 50.00 & 7 & 46.67 & 1 & 14.29 \\
\hline No & 11 & 50.00 & 8 & 53.33 & 6 & 85.71 \\
\hline $\begin{array}{l}\text { Does your institution } \\
\text { provide staff / } \\
\text { faculty training for } \\
\text { OER development } \\
\text { and adoption }\end{array}$ & & & & & & \\
\hline Yes & 20 & 90.91 & 15 & 100.00 & 3 & 42.86 \\
\hline No & 2 & 9.09 & 0 & 0.00 & 4 & 57.14 \\
\hline
\end{tabular}

Overall, most of the respondents from each type of institutional system (the Universities System, the Rajabhat Universities System, and the Rajamangala Universities of Technology System) have positive attitudes toward OER development, whether they focus on the main area, main reason, or staff and faculty development.

\section{3) OER infrastructure, support and incentives}

The respondents further indicated the infrastructure that each university may need to put in place in terms of developing a stronger culture of sharing, learning, and teaching resources on an open basis (Table VII). These included a university's repository, the university's presence on an open website, incentives, IT technical assistance, staff and faculty development, and other suggestions.

For the Universities System, respondents indicated IT technical assistance $(81.82 \%)$ to be the main infrastructure, 
followed by staff and faculty development (68.18\%), a university repository only open to students and staff $(68.18 \%)$, a university presence on an open website such as iTuneU, YouTube Edu, Google Edu, and others (63.64\%), and incentives for those who develop resources $(45.45 \%)$ that their universities should focus on in terms of developing more of a culture of sharing, learning, and teaching resources on an open basis.

For the Rajabhat Universities System, staff and faculty development is the main form of support (80\%), followed by IT Technical assistance (73.33\%), a university presence on an open website such as iTuneU, YouTube Edu, Google Edu, and others $(63.64 \%)$, a university repository only open to students and staff $(46.67 \%)$, and incentives for those who develop resources $(40 \%)$.

For the Rajamangala Universities Technology System, incentives for those who develop resources $(42.86 \%)$ is the main form of support, followed by a fairly evenly distribution regarding a university repository only open to students and staff (28.57\%), a university presence on an open website such as iTuneU, YouTube Edu, Google Edu, and others (28.57\%), IT technical assistance $(28.57 \%)$, and staff and faculty development $(28.57 \%)$.

TABLE VII: PERCEPTIONS OF INFRASTRUCTURE, SUPPORT AND INCENTIVES FOR DEVELOPING A CULTURE OF SHARING

\begin{tabular}{|c|c|c|c|c|c|c|}
\hline \multirow{2}{*}{$\begin{array}{l}\text { In your opinion, what } \\
\text { infrastructure, support, } \\
\text { and incentives would } \\
\text { the university need to } \\
\text { put in place to develop } \\
\text { more of a culture of } \\
\text { sharing of learning and } \\
\text { teaching resources on } \\
\text { an open basis? }\end{array}$} & \multicolumn{2}{|c|}{$\begin{array}{l}\text { Universities } \\
\text { System (US) }\end{array}$} & \multicolumn{2}{|c|}{$\begin{array}{l}\text { Rajabhat } \\
\text { Universities } \\
\text { System } \\
\text { (RUS) }\end{array}$} & \multicolumn{2}{|c|}{$\begin{array}{l}\text { Rajamangala } \\
\text { Universities of } \\
\text { Technology } \\
\text { System } \\
\text { (RUTS) }\end{array}$} \\
\hline & F & $\%$ & F & $\%$ & $\mathrm{~F}$ & $\%$ \\
\hline $\begin{array}{l}\text { A university repository } \\
\text { only open to students } \\
\& \text { Staff }\end{array}$ & 15 & 68.18 & 7 & 46.67 & 2 & 28.57 \\
\hline $\begin{array}{l}\text { A university presence } \\
\text { on an open website } \\
\text { such as iTuneU, } \\
\text { YouTube Edu, Google } \\
\text { Edu, etc. }\end{array}$ & 14 & 63.64 & 9 & 60.00 & 2 & 28.57 \\
\hline $\begin{array}{l}\text { Incentives for those } \\
\text { who develop resources }\end{array}$ & 10 & 45.45 & 6 & 40.00 & 3 & 42.86 \\
\hline $\begin{array}{l}\text { IT/Technical } \\
\text { assistance }\end{array}$ & 18 & 81.82 & 11 & 73.33 & 2 & 28.57 \\
\hline $\begin{array}{l}\text { Staff \& Faculty } \\
\text { development }\end{array}$ & 15 & 68.18 & 12 & 80.00 & 2 & 28.57 \\
\hline
\end{tabular}

\section{Overview of Current Status and Practice of USR from Respondents}

This section examines the participants' opinions based on respondent answers regarding the current USR status and practices including 1) USR strategy and policy and 2) USR practice according to each category.

\section{1) Current status of USR strategy and policy}

The respondents from Universities System indicated $68.18 \%$ that their institutions have a strategy or policy for university social responsibility (Table VIII). Some of the respondents have stated that social engagement and physical, environmental, and facility impact are all part of the USR strategy in their universities. In addition, conducting research that has direct or indirect benefits the society under the category of academic service is part of USR strategy practice in the Universities System.

A larger percentage, $73.33 \%$ of the Rajabhat Universities System respondents, indicated that their institutions have a strategy or policy for university social responsibility. Most of the respondents have stated that there is a policy for moral and social responsibility research and development included as part of academic service research with the aim of solving problems and developing a better living quality for the local community and society of the Rajabhat Universities System.

However, only $42.86 \%$ of the Rajamangala Universities Technology System respondents indicated that their institutions have a strategy for university social responsibility. This USR strategy is indicated in the Rajamangala Universities Technology System that provides academic services to promote creation of jobs and competitive potential as part of the strategic plan.

TABLE VIII: STATUS OF CURRENT USR STRATEGY \& POLICY

\begin{tabular}{|c|c|c|c|c|c|c|}
\hline \multirow{2}{*}{$\begin{array}{l}\text { Does your institution } \\
\text { currently have a } \\
\text { strategy or policy for } \\
\text { university social } \\
\text { responsibility } \\
\text { (USR)? }\end{array}$} & \multicolumn{2}{|c|}{$\begin{array}{l}\text { Universities } \\
\text { System (US) }\end{array}$} & \multicolumn{2}{|c|}{$\begin{array}{l}\text { Rajabhat } \\
\text { Universities } \\
\text { System (RUS) }\end{array}$} & \multicolumn{2}{|c|}{$\begin{array}{l}\text { Rajamangala } \\
\text { Universities of } \\
\text { Technology } \\
\text { System (RUTS) }\end{array}$} \\
\hline & $\mathrm{F}$ & $\%$ & $\mathrm{~F}$ & $\%$ & $\mathrm{~F}$ & $\%$ \\
\hline Yes & 15 & 68.18 & 11 & 73.33 & 3 & 42.86 \\
\hline No & 7 & 31.82 & 4 & 26.67 & 4 & 57.14 \\
\hline
\end{tabular}

\section{2) Current USR practice according to each category}

The current USR practices regarding social responsibility vary in terms of their impact, and do so according to each category including: (1) social, (2) sub-social, (3) cognitive, (4) organizational, (5) philanthropic, (6) economic, (7) ethical, (8) environmental, and (9) educational impacts, as illustrated in Table IX. The Universities System focused more on: human rights $(72.73 \%)$; sustainable human development $(72.73 \%)$ in the social dimension; work-life balance $(72.73 \%)$ in the sub-social dimension; ethnicity $(59.09 \%)$ in the cognitive dimension; the aforementioned aspects including management ethics \& work culture $(63.64 \%)$ in the organizational dimension; university volunteering (77.27\%) in the philanthropic dimension; transparency $(81.82 \%)$ in the economic dimension; copyright protection $(63.64 \%)$ in the ethical dimension; environmental organizational structure such as recycling and energy saving $(86.36 \%)$ in the environmental dimension; and raising student awareness $(86.36 \%)$ in the educational dimension.

Moreover, the respondents from the Rajabhat Universities System highlighted slightly different aspects as compared to the Universities System. According to the SCOPE framework, they noted: sustainable human development $(86.67 \%)$ in the social dimension; work-life balance $(80 \%)$ in the sub-social dimension; poverty $(80 \%)$ in the cognitive dimension; management ethics $(80 \%)$ in the organizational dimension; university volunteering (80\%) in the philanthropic dimension; quality and safety of provided products and services (60\%) in the economic dimension; code of ethics $(80 \%)$ in the ethical dimension; natural resource protection $(80 \%)$ in the environmental dimension; and stakeholder awareness of values and an understanding of the society that they are part of $(80 \%)$ in the educational 
dimension.

Furthermore, the responses from the Rajamangala Universities of Technology System do indicate some similarity in USR practices with the Rajabhat Universities System. For example, in the social (sustainable human development, 85.71\%), cognitive (poverty, 42.86\%), organizational (management ethics $71.43 \%$ ), philanthropic (university volunteering, 100\%), ethical (code of ethics, $71.43 \%$ ), and educational (stakeholder awareness of values and an understanding of the society that they are part of, $85.71 \%$ ) dimensions, respondents indicated the same aspect as the respondents from the Rajabhat Universities System. However, there were some differences in the areas being noted, for example work-life balance $(28.57 \%)$ and faculty and staff training $(28.57 \%)$ in the sub-social dimensions, transparency $(85.71 \%)$ in the economic dimensions, environmental organizational structure such as cycling and energy saving $(28.57 \%)$ and natural sources protection $(28.57 \%)$ in the environmental dimension.

\section{Opinion, Perception, and Attitude toward OERs \& USR}

This section interprets respondents' opinions toward OERs and USR within their particular context. Respondents provided information and opinions regarding perceptions of the current effect of OERs on the learning environment and university administration management and offered some suggestions to integrate both OERs and USR for university management.

\section{1) The universities system}

15 out of 22 respondents $(68 \%)$ indicated the OERs may potentially support teaching and learning for faculty members, staff, and students within the universities because they believed OERs could help broaden information searches and enable learning opportunities to occur at any time and in any place. They further indicated that OERs play a role in educational responsibility in that they serve the community and give the university the advantage of being useful to its stakeholders. Thus, respondents suggested that Thai HEIs need to create connections with the local community, provide educational opportunities for society through meeting their educational needs, and create knowledge resources and references as part of OER development. Therefore, integrating OERs and USR into university strategic planning is one of the main responsibilities for Thai HEIs.

\section{2) The Rajabhat universities system}

10 out 15 respondents $(66 \%)$ had positive attitudes towards OERs, believing them to have a positive impact on the learning environment and university administration management. For example, one of the respondents indicated that OERs could help learners to have more options regarding access to learning resources, and could, with persistent effort, help create a better learning atmosphere. Another respondent perceived OERs to be helpful to the learning process through making it more efficient for students to create various learning resources. OERs allow learners to exchange knowledge and resources and apply that knowledge to solving future problems, encouraging and enabling a better understanding between students of different nations. When using OERs as part of a database system or repository, every level of a university can adapt to many situations by using OERs to improve teaching, learning, and working. OER is an important resource that could be used to drive economic and social movements. Therefore, respondents suggested the need to increase understanding regarding OER benefits to the learning process, a need that exists at every level of the university. Thus, both OERs and USR should be integrated into university strategic planning in order to establish the desired vision of openness at the university.

TABLE IX: PERCEPTIONS OF THE IMPACTS OF MAJOR USR SCOPE PRACTICES

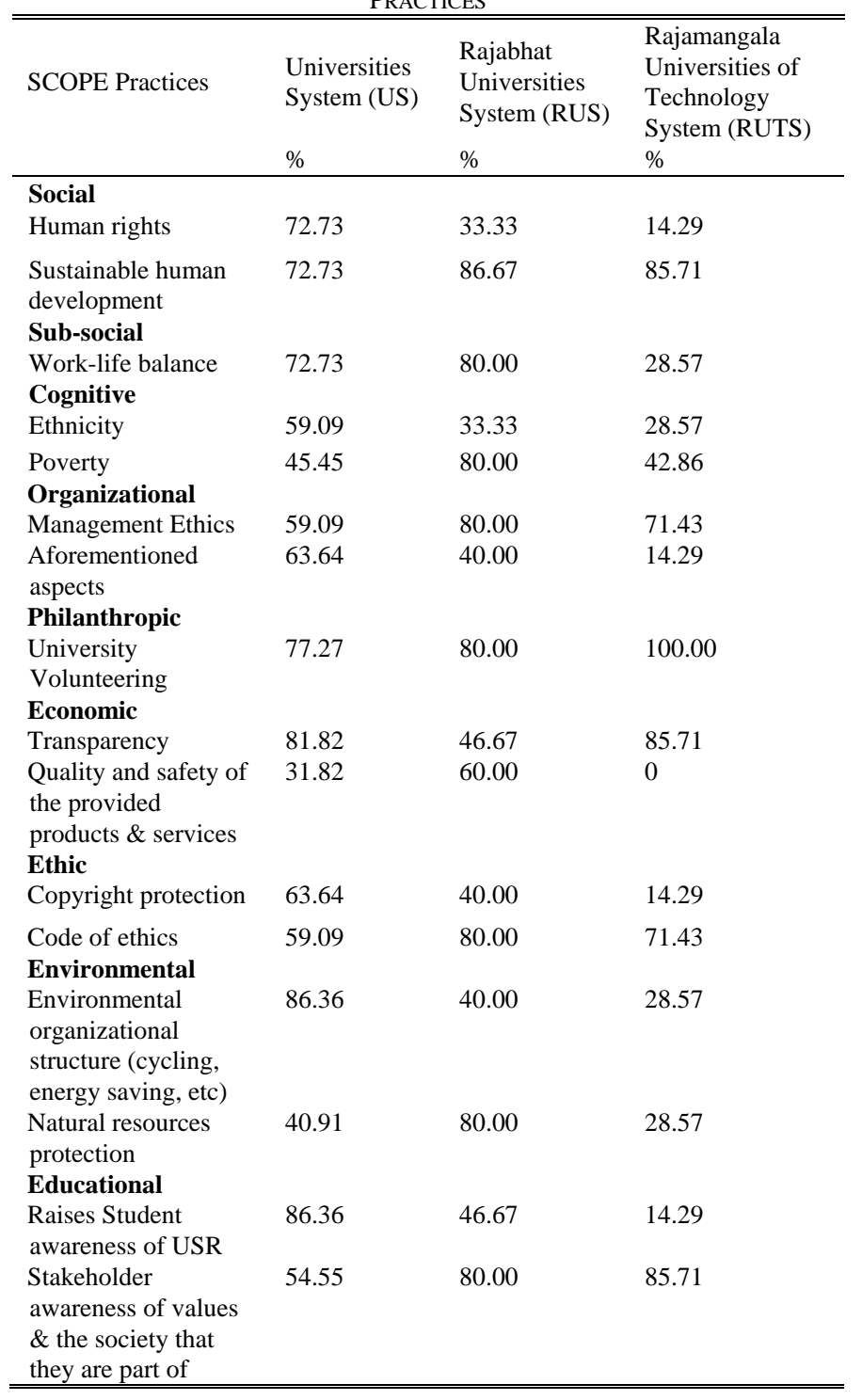

\section{3) The Rajamangala universities technology system}

7 out of 9 respondents (77\%) commented on the current impact of OERs on the university learning environment and administrative management, which included that: (1) OERs allow students and faculty members to access and apply useful knowledge that could aid their self-development in the fields of teaching, learning, and research; (2) OERs could support continuous learning development as part of a lifelong learning policy since the learning resources are being used and reused; and (3) OERs could help the universities to create a superior vision and path towards the allocation of suitable personnel to suitable work and resources. Thus, respondents 
suggested that OERs could be used to promote the university and improve the social responsibility practices of the universities, in addition to transferring the learning process from a traditional approach to one which better benefits the salient of the day and has more beneficial effects on society, culture, and ethics. Therefore, there is a need to create a clear understanding, educating university managers at Thai HEIs on the benefits of OERs and USR, with the aim of establishing a university strategic plan at both a university and faculty level.

\section{DISCUSSION AND IMPLICATIONS}

The findings of this study should be discussed within the context of each university system. First, the majority of respondents from the Universities System, the Rajabhat Universities System, and the Rajamangala Universities of Technology System had positive attitudes toward OERs, and perceived OERs as having a positive impact on the learning environment. However, increasing OER awareness in different levels of universities; increasing the level of knowledge and resource exchange in terms of openness for teaching and learning; increasing opportunities for students, staff, and faculty members; and establishing clear OER guidelines were all considered to be in need of further consideration by university management. Second, establishing a multi-channel system for OER creation, distribution, and development; providing strategies to support USR practices throughout the creation of open content; and establishing higher standards of quality for open learning materials all need to be better incorporated into university strategic planning.

In addition, the findings of this study may better establish the concept of university social responsibility (USR) considered in previous studies [10], [11], [17], [25], [30], [31]. By considering a variety of USR practices in each component, Thai HEIs could really fulfill their social role and could better present evidence of commitment to both stakeholder and community through the openness of their knowledge creation and transformation. This supports the existing literature [9] regarding the key features of social responsibility, which a university may follow, which could include bringing a university to a higher level of innovation in sustaining future educational frameworks.

Moreover, the findings of this study hopefully provides benefits to scholars in the field of educational technology or university policy creation and administration, particularly with regards to supporting existing educational strategy planning, and may perhaps move educational policy development further along. This study might also raise awareness of the linkage between USR and OER practices for different types of universities, and aid toward the establishment of socially responsible universities by moving toward building a more open knowledge-based society. In these specific cases, the university policy makers might wish to focus on the development of each component of USR and, with the proper funding support, move their nations toward being a more open knowledge-based society.

There are a number of implications that need to be considered in future research. First, most Thai HEIs have indicated having an OER strategic plan. However, when examined closely, more strategic planning is likely needed in the areas of existing eLearning practice. Hence, looking forward, more research and a greater allocation of budget is needed from university management. Second, although respondents have indicated addressing the issues of university social responsibility, most practice and strategic planning are focused on achieving academic service. Thus, further investigation of the components of USR, its practices, and how exactly one may create impactful USR should be examined in future. Thirdly, existing investigations are difficult to compare due to the differences in the university types. The major challenge is the lack of appreciation and process with respect to OER and USR practices.

\section{CONCLUSION AND RECOMMENDATION}

This study considered the opinions and attitudes of university managers within the tripartite Thai University System towards OERs and USR within the Thai context. This focus on social responsibility practices may in turn encourage Thai universities to expand their roles and services with a managerial emphasis by taking their role as an agent of social change more seriously and thereby moving to higher levels of achievement and responsibility. In this way, they may better fulfill their potential in the areas of social practice, social movement, and social change, achieved through the means of open educational resource creation and provision. Many of the questions and concerns regarding OER development for the next decade still remain to be solved. These issues require serious consideration not only for individuals, but also for HEIs with respect to all human beings, their rights, and the roles they play within their personal and professional practices. Ideally, OERs will become another public social service and practice that every HEI provides to society. Thus, this researcher recommends policy makers, planners and university managers, especially those involved in the strategic planning sector, to take into serious consideration the integrating of OERs and USR practice as part of university strategic planning. Future research may consider other facts of the growing OER and USR movement at the individual, institutional, and national level.

\section{REFERENCES}

[1] P. Arnold, "Open educational resources: The way to go, or "mission impossible" in (German) higher education," presented at 2012 Prato CIRN Community Information Conf., 2012.

[2] G. Geser, "Open educational practices and resources," OLCOS Roadmap, 2012.

[3] I. Peña-López, "Giving knowledge for free: The emergence of open educational resources," OECD Publishing, May 2007.

[4] UNESCO. (2012). World open educational resources congress (OER). [Online]. Available: http://www.unesco.org/new/fileadmin/MULTIMEDIA/HQ/CI/CI/pdf/ themes/HewlettQuestionnaire_English.pdf

[5] S. Schaffert and G. Geser, "Open educational resources and practices," eLearning Papers, no. 7, Feb. 2008.

[6] N. Butcher, "Open educational resources and higher education," Retrieved, July 2010

[7] D. Wiley, "Openness as catalyst for an educational reformation," EDUCAUSE Review, vol. 45, no. 4, pp. 14-20, July 2010.

[8] D. Wiley, "The open future: Openness as catalyst for an educational reformation," EDUCAUSE Review, pp. 15-20. 2010. 
[9] D. Willey. The access compromise and the $5^{\text {th }}$ R. [Online]. Available: http://opencontent.org/blog/archives/3221

[10] F. Vallaeys, "Defining social responsibility: A matter of philosophical urgency for university," Recuperado de, May 2013.

[11] A. Esfijani, F. K. Hussain, and E. Chang, "An approach to university social responsibility ontology development through text analyses," in Proc. IEEE 5th International Conference on Human System Interactions, IEEE-HSI-2012. IEEE Computer Society, pp. 1-7, 2012.

[12] A. Esfijani and E. Chang, "A fuzzy logic based approach for measuring virtual university social responsibility," presented at 2nd World Conference on Soft Computin, 2012.

[13] A. Esfijani and E. Chang, "Metrics development for measuring virtual university social responsibility," presented at IEEE 12th International Conference on Advanced Learning Technologies, pp. 724-725, 2012.

[14] S.-H. Chen, J. Nasongkhla, and J. A. Donaldson, "University social responsibility (USR): Identifying an ethical foundation within higher education institutions," Turkish Online Journal of Educational Technology, vol. 14, no. 4, pp. 165-172, Oct 2015.

[15] S.-H. Chen, "A strategic planning model for developing open educational resources," Chulalongkorn University, Bangkok, Thailand, 2015.

[16] UNESCO. (2012). 2012 Paris OER Declaration. [Online]. Available: http://www.unesco.org/new/fileadmin/MULTIMEDIA/HQ/CI/CI/pdf/ Events/Paris OER Declaration_01.pdf

[17] AUN. (2012) AUN USR and S: University social responsibility and sustainability. [Online]. Available: http://www.aunsec.org/pdf/aunwebsite/usrsppocketbook.pdf

[18] A. M. Dima, S. Vasilache, V. Ghinea, and S. Agoston, "A model of academic social responsibility," Transylvanian Review of Administrative Sciences, vol. 9, no. 38, pp. 23-43, Feb 2013.

[19] S. Hoosen, "Survey on governments' open educational resources (OER) policies," World OER Congress, 2012.

[20] N. Butcher, S. Uvalić-Trumbić, and A. Kanwar, "A basic guide to open educational resources (OER)," Vancouver and Paris: COL and UNESCO, 2011.

[21] ISO 26000. (2012). Social Responsibility. [Online]. Available: http://www.iso.org/iso/home/standards/iso26000.html

[22] M. R. Karimi, "Designing the conceptual model of social responsibility at Azad University through its public relations role," African Journal of Business Management, vol. 7, no. 1, pp. 8-21, Jan. 2013.

[23] K. A. Paris, "Strategic planning in the university," University of Wisconsin System Board of Regents, USA, Nov 2003.

[24] J. Pookyaporn, "University social responsibility: Southeast Asia," 2011 CGE Annual Meeting, Sep. 2011.

[25] L. Tetrevova and V. Sabolova, "University stakeholder management and university social responsibility," WSEAS Transactions on Advances in Engineering Education, vol. 7, no. 7, pp. 224-233, July 2010.
[26] J. F. Trainer, "Models and tools for strategic planning," New Directions for Institutional Research, vol. 2004, no. 123, pp. 129-138, Dec. 2004.

[27] UNESCO, \& COL. (2012). Guidelines for open educational resources (OERs) in higher education, 2012. [Online]. Available: http://unesdoc.unesco.org/images/0021/002136/213605e.pdf

[28] D. Wiley, "On the sustainability of open educational resource initiatives in higher education," 2007.

[29] R. C. Turner and L. Carlson, "Indexes of item-objective congruence for multidimensional items," International Journal of Testing, vol. 3, no. 2, pp. 163-171, 2003

[30] J. Reiser. (2007). Managing university social responsibility. International Sustainable Campus Network: Best Practices - Future Challenges. [Online]. Available: http://www.international-sustainable-campus-network.org/downloads/ conference-and-symposia/iscn-conference-2007/108-panel-b1-juan-re iser-pontificia-universidad-catolica-del-peru/file

[31] R. Vasilescu et al., "Developing university social responsibility: A model for the challenges of the new civil society," Review of Procedia - Social and Behavioral Sciences, vol. 2, no. 2, pp. 4177-4182, 2010.

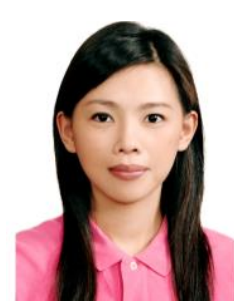

Shu-Hsiang Chen is currently working as ASEAN marketing consultant at Chilitage Technology Co., Ltd., Kaohsiung City, Taiwan. She is also working as adjunct assistant professor in the universities of southern Taiwan. Her current research focus on open educational resources, technology integration into business and education, and university social responsibility.

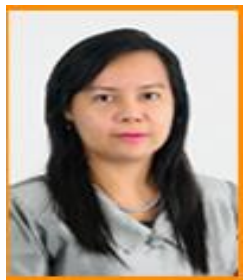

Jaitip Nasongkhla is an associate professor, heads of the Department of Educational Technology and Communications, and director of Innovative Network of Educational Technology Research Center (iNet), Faculty of Education, Chulalongkorn University, Bangkok, Thailand, with expertise in educational technology, teacher education, and teaching methods.

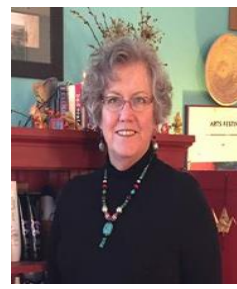

J. Ana Donaldson is past president of Association for Educational Communications and Technology (AECT), and retired associate professor of instructional technology at University of Northern Iowa, USA, with expertise in engaging the online learner, educational technology, and adult education. 